\title{
The Perlman Exception: Limitations Required By The Final Decision Rule
}

Section 1291 of the Judicial Code allows appeal to the courts of appeals "from all final decisions of the district courts of the United States." Orders compelling testimony before grand juries or denying motions to quash subpoenas to appear before grand juries are not final decisions and therefore are not immediately appealable. ${ }^{2}$ Subpoenaed parties must either comply with these orders or resist them, inviting a contempt citation. The contempt sanction is an immediately appealable final decision, ${ }^{3}$ thus providing witnesses a route for prompt review of ordinarily nonappealable, interlocutory orders. ${ }^{4}$

The Perlman exception ${ }^{5}$ to this general rule gives a thirdparty intervenor claiming a constitutional, statutory, or common law privilege in subpoenaed information the right to immediate appeal because he is not in a position to be cited for contempt. This exception provides that where a subpoenaed party will not risk a contempt citation to render an intervenor's claim appealable, and the intervenor thus will lose any meaningful opportunity to have the claim reviewed, a court's refusal to quash a grand jury subpoena may be deemed an appealable final decision under section $1291 .^{\circ}$

The Supreme Court continues to endorse the Perlman exception in dicta without much guidance as to its precise scope, ${ }^{7}$ and the circuits disagree on the breadth of the exception. Most apply it

28 U.S.C. § 1291 (1976).

2 United States v. Ryan, 402 U.S. 530, 533 (1971); Cobbledick v. United States, 309 U.S. 323, 325 (1940); Alexander v. United States, 201 U.S. 117, 121 (1906).

s United States v. Ryan, 402 U.S. 530, 533 (1971). The proceedings may be stayed until the appeal is completed. Lowthian v. United States, 575 F.2d 1292, 1293 (9th Cir. 1978) (per curiam). See 28 U.S.C. \& 1826 (1976) (court should expedite appeal from contempt order).

- See Alexander v. United States, 201 U.S. 117, 121-22 (1906) (recognizing review through contempt citation).

- The exception derives its name from Perlman v. United States, 247 U.S. 7 (1918).

- Typically, the subpoenaed party initially seeks to quash the subpoena, claiming that the information sought is protected by his own and the intervenor's privileges. If the court issues an order denying the subpoenaed party's motion to quash, the intervenor may formally intervene, has standing to file and appeal, and may assert the privilege in his own right. The Perlman exception governs this appeal.

The most recent endorsement was in United States v. Nixon, 418 U.S. 683, 691 (1974). 
liberally to a variety of situations, ${ }^{8}$ but a distinct minority limits its application. ${ }^{\circ}$

After reviewing the policies underlying section 1291 and comparing the Perlman exception with other exceptions to the final decision rule, ${ }^{10}$ this comment proposes a framework for applying the Perlman exception. Using this framework, the comment then analyzes typical situations in which intervenors seek to invoke the exception. The analysis demonstrates the undesirability of a wholesale expansion of the exception, and the comment concludes that the congressional directive in section 1291 and the need to protect appellate courts from burdensome interlocutory appeals compel a narrow reading of the Perlman exception.

\section{The Perlman Exception}

\section{A. The Final Decision Rule}

In enacting section 1291, Congress determined that the concerns of a litigant seeking immediate review of an interlocutory order are not sufficiently compelling to outweigh the importance of conserving judicial resources and avoiding interruptions in judicial proceedings. ${ }^{11}$ Applying this congressional directive, the Supreme

- Most notable are the Third, Fifth, and Eighth Circuits. See, e.g., In re Grand Jury Proceedings, 655 F.2d 882 (8th Cir. 1981) (client-intervenor, claiming attorney-client privilege, may invoke Perlman exception to appeal an order denying motion to quash grand jury subpoena issued to attorney); In re Grand Jury Proceedings, 641 F.2d 199 (5th Cir. 1981) (same); In re Grand Jury Proceedings, 604 F.2d 798 (3d Cir. 1979) (same); United States v. RMI Co., 599 F.2d 1183 (3d Cir. 1979); In re Grand Jury Investigation, 587 F.2d 589 (3d Cir. 1978); In re Grand Jury Proceedings, 563 F.2d 577 (3d Cir. 1977).

- Most notable are the District of Columbia, First, and Second Circuits. See, e.g., In re Sealed Case, 655 F.2d 1298 (D.C. Cir. 1981) (client-intervenor, claiming attorney-client and work product privileges, may not invoke the Perlman exception to appeal an order denying motion to quash grand jury subpoena issued to attorney); In re Oberkoetter, 612 F.2d 15 (1st Cir. 1980) (same, except client-intervenor asserted only attorney-client privilege); National Super Spuds, Inc. v. New York Mercantile Exch., 591 F.2d 174 (2d Cir. 1979) (employer-intervenor, claiming governmental privilege, may not use Perlman exception to appeal an order denying motion to quash grand jury subpoena issued to employee).

10 Although sometimes termed the "final judgment" rule, see Frank, Requiem for the Final Judgment Rule, 45 TEx. L. Rev. 292 (1966), section 1291 refers to decisions, not judgments.

${ }^{11}$ See New York Times Co. v. Jascalevich, 439 U.S. 1304, 1305 (1978) (Marshall, J., in chambers) (noting strong congressional policy of hastening ultimate disposition of litigation); United States v. Nixon, 418 U.S. 683,690 (1974) (finality requirement conserves judicial resources by avoiding piecemeal appellate review). See also Crick, The Final Judgment as a Basis for Appeal, 41 Yals L.J. 539 (1932) (history of the rule's common law background); Frank, supra note 10, at 292 ("In the federal system the requirement of a final judgment for appellate review was incorporated in the Judiciary Act of 1789 and has been carried forth, with some specified exceptions, in every subsequent revision of the judicial 
Court has ruled that to obtain immediate review of orders in criminal or civil actions compelling testimony or production of evidence, a subpoenaed witness must be prepared to disobey the order and suffer a contempt citation. ${ }^{12}$

The harshness of the choice between compliance and contempt cannot be denied. If the witness suffers contempt to perfect an appeal, he remains a contemnor, subject to imprisonment or fine, unless the appellate court quashes the subpoena. ${ }^{13}$ By imposing this difficult choice on the witness contemplating an appeal, however, the rule maintains efficient judicial administration, prevents unnecessary delays, and guards against circumvention of section 1291's finality requirement. ${ }^{14}$

code.").

Conditioning appealability on a final decision serves other purposes. Consolidating review of all the issues of a case in a single, comprehensive proceeding may foster betterinformed decisions. See, e.g., Baltimore Contractors, Inc. v. Bodinger, 348 U.S. 176, 178 (1955); Heike v. United States, 217 U.S. 423, 428-29 (1910); McLish v. Roff, 141 U.S. 661, 665-66 (1891); 9 J. Moore, B. Ward \& J. Lucas, Moore's Federal Practice II 110.07, at 107-11 (2d ed. 1980) [hereinafter cited as Moore's Federar Practice]. The finality requirement of section 1291 respects the role of trial judges in determining the myriad legal and factual issues arising during trial. Such determinations will be accorded deference on appeal. See Firestone Tire \& Rubber Co. v. Risjord, 449 U.S. 368, 374 (1981).

12 United States v. Ryan, 402 U.S. 530, 533 (1971); Cobbledick v. United States, 309 U.S. 323, 325 (1940); Alexander v. United States, 201 U.S. 117, 121 (1906).

13 The Supreme Court's decisions formulating the rule requiring the witness's submission to a contempt citation have failed to indicate whether the citation would be criminal or civil. Contempt proceedings cannot be characterized as strictly criminal or civil within the ordinary meaning of those terms. See, e.g., Myers v. United States, 264 U.S. 95, 103 (1924). Courts must classify the contempt citation, however, because the criminal contemnor is protected by constitutional guarantees that are unavailable to the civil contemnor. See Kuhns, The Summary Contempt Power: A Critique and a New Prospective, 88 Yale L.J. 39 (1978).

The classification usually depends on the purpose of the citation. The purpose of civil contempt is to coerce the witness into complying with the court's order. The penalty, either fine or imprisonment, is terminable upon the contemnor's compliance with the order. In other words, civil contemnors "carry the keys of their prison in their own pockets." In re Nevitt, 117 F. 448, 461 (8th Cir. 1902). Criminal contempt, on the other hand, is designed to punish the contemnor who flouts the court's order. See, e.g., Gompers v. Bucks Stove \& Range Co., 221 U.S. 418, 441 (1911). The penalty is imprisonment for a fixed term, and, unlike civil contemnors, criminal contemnors cannot purge themselves by complying with the court's order. Id. at $442-43$.

In practice, nonparty witnesses who suffer contempt to perfect appeals are cited for civil contempt. See, e.g., National Super Spuds, Inc. v. New York Mercantile Exch., 591 F.2d 174, 180 (2d Cir. 1979). The court achieves the aim of forcing compliance by threatening civil fines, which continue until the witness complies, the grand jury is dismissed, or the witness prevails on appeal. Criminal contempt is inappropriate for nonparty witnesses because it would eliminate any ongoing incentive for the witness to comply with the subpoena.

14 United States v. Ryan, 402 U.S. 530, 533 (1971). Accord, Maness v. Meyers, 419 U.S. 449, 460 (1975); United States v. Nixon, 418 U.S. 683, 690-91 (1974). See also DiBella v. United States, 369 U.S. 121, 124 (1962) (Frankfurter, J.) ("This insistence on finality and prohibition of piecemeal review discourages undue litigiousness and leaden-footed adminis- 


\section{B. The Perlman Exception}

In Perlman v. United States, ${ }^{16}$ the Supreme Court created an exception to the rule requiring a contempt citation to perfect an appeal. The facts were unusual. Perlman deposited his papers and models with the clerk of the district court as exhibits in a patent infringement suit brought by his company. Later the district court, on application of the United States Attorney, directed the clerk to produce the exhibits for presentation to a grand jury that was investigating charges that Perlman had perjured himself in the patent suit. ${ }^{16}$ Claiming fourth and fifth amendment privileges in the exhibits, ${ }^{17}$ Perlman unsuccessfully petitioned to restrain their presentation to the grand jury. ${ }^{18}$ The government moved to dismiss Perlman's appeal of this ruling, arguing that because the district court's order was part of an ongoing proceeding, it was interlocutory and therefore not appealable. ${ }^{10}$

The Court rejected this argument, reasoning that Perlman's ability to protect his constitutional privileges would be thwarted if he could not appeal the district court's ruling. Because Perlman was powerless to prevent disclosure and to "avoid the mischief of the [production] order," the Court held the order "final" for purposes of appeal. ${ }^{20}$

Subsequent Court decisions initially interpreted Perlman to permit appeals of interlocutory orders where the petitioner's mo-

tration of justice, particularly damaging to the conduct of criminal cases."); Cobbledick v. United States, 309 U.S. 323, 325 (1940) (Frankfurter, J.). See also 9 Moore's Fedrar. PracTICE, supra note 11, I 110, § 13[2], at 155:

Sufferance of a contempt conviction is a desperate remedy, but no less desperate is the disease that the remedy was designed to relieve. Litigation cannot go on if those involved are allowed to interrupt it with impunity to take appeals that are usually foredoomed to failure. The issues raised by such appeals have been committed by Congress and the Federal Rules to the discretion of the district courts. For patent abuse of discretion, or to settle "new and important problems" respecting the power of the district court, mandamus is available.

is 247 U.S. 7 (1918).

1* See Perlman Rim Corp. v. Firestone Tire \& Rubber Co., 244 F. 304 (S.D.N.Y. 1917).

17247 U.S. at 13.

14 In light of current jurisprudence on fourth amendment-standing-requirements, it is doubtful that Perlman would be able to raise his fourth amendment claim today. See Rakas v. Illinois, 439 U.S. 128 (1978).

10 247 U.S. at 13.

${ }^{20}$ Id. The Court rejected Perlman's arguments on the merits, holding that because he had voluntarily produced the exhibits to his advantage as part of his testimony in an earlier patent suit, he suffered no invasion of his fourth and fifth amendment privileges. Id. at 15. In other words, Perlman had no basis for arguing that the district court's subpoena constituted an "unreasonable seizure" or "forced compulsory" self-incriminating testimony. 
tion to quash was independent of the pending proceeding. ${ }^{21}$ The Perlman exception eventually was narrowed to allow an intervenor claiming an interest in the subpoenaed information to appeal the denial of his motion to quash that subpoena, where the subpoenaed party could not be expected to risk contempt to perfect an appeal. ${ }^{22}$ This narrowing also involved a subtle shift in the underlying explanation for the exception. In Cobbledick $v$. United States, ${ }^{23}$ the Court in 1940 emphasized the impossibility of later review as the reason for allowing Perlman to appeal. When the Court resurrected the Perlman exception in the 1970's, ${ }^{24}$ however, it emphasized as the reason for allowing appeal the uncertainty of having the subpoenaed party risk contempt to aid the intervenor. ${ }^{25}$

Besides these intermittent endorsements of the Perlman exception, the Court has not provided concrete guidelines for its application. It is unclear whether the exception applies to both constitutional and nonconstitutional claims of intervenors, ${ }^{26}$ and it is

21 See Go-Bart Importing Co. v. United States, 282 U.S. 344, 356 (1931) (citing Perlman for the proposition that if the district court's order was not made in, or dependent on, any pending case or proceeding, the order was appealable); Cogen v. United States, 278 U.S. 221, 225 (1929) (Perlman conferred appealability on the interlocutory order because of the independence of Perlman's motion to quash from the criminal proccedings involving the perjury charges).

${ }_{22}$ See United States v. Nixon, 418 U.S. 683, 691 (1974); United States v. Ryan, 402 U.S. 530, 533 (1971); Cobbledick v. United States, 309 U.S. 323, 328-29 (1940).

23309 U.S. 323, 328-29 (1940).

24 Perlman had to be "resurrected" because of the Court's decision in DiBella v. United States, 369 U.S. 121 (1962). In that case, the Court held that appeals from orders granting or denying pre-indictment motions were not appealable. Id. at 131. The Court's broad language signalled the preclusion of a Perlman-type appeal. See National Super Spuds, Inc. v. New York Mercantile Exch., 591 F.2d 174, 179 (2d Cir. 1979) (Friendly, J.) (DiBella spelled "the doom of Perlman"). As Judge Friendly has pointed out, however, "predictions of Perlman's demise would have been as exaggerated as those of Mark Twain's." Id. In United States v. Ryan, 402 U.S. 530, 537 (1971), the Court approved Perlman as one decision in a "limited class of cases" where denial of immediate review would render impossible any review whatsoever of an individual's claim, so that an exception to the final decision rule was necessary. The Court's most recent affirmation of Perlman came in United States v. Nixon, 418 U.S. 683,691 (1974).

${ }^{25}$ See United States v. Ryan, 402 U.S. 530, 533 (1971).

28 Perlman involved a constitutional claim. See supra notes 15-20 and accompanying text. In Cobbledick v. United States, 309 U.S. 323, 328-29 (1940), Justice Frankfurter cited Perlman's constitutional claim as a factor in the Court's decision. In United States v. Ryan, 402 U.S. 530 (1971), however, the Court did not highlight the constitutional nature of Perlman's claim, possibly minimizing its significance. In United States v. Nixon, 418 U.S. 683 (1974), the Court cited Perlman as involving simply "a claim of privilege," again without distinguishing among constitutional, statutory, and common law privileges. Id. at 691 . In the Court's latest message, Justice Marshall read-Perlman as allowing appeals so that the petitioner could assert its "constitutional objections" to the subpoena. Eastland v. United States Servicemen's Fund, 421 U.S. 491, 514 (1975) (Marshall, J., concurring).

Although the First Circuit has argued that the Perlman exception applies only to con- 
also unclear to what extent the relationship between the intervenor and the subpoenaed party determines the scope of the exception.

\section{Exceptions to the Final Decision Rule: Alternatives to Perlman}

Congress and the Supreme Court have created additional exceptions to the finality requirement to mitigate its sometimes harsh results. These other exceptions, however, do not guarantee the third-party intervenor in a Perlman-type situation an immediate, nondiscretionary review of his claim.

For example, the Interlocutory Appeals Act, ${ }^{27}$ codified at section 1292(b) of the Judicial Code, permits trial judges to certify for appeal orders in civil actions that involve "controlling question[s] of law" when an immediate appeal may "materially advance the ultimate termination of the litigation." Some courts have certified for appeal orders involving grand jury subpoenas where appellants would otherwise be precluded from asserting claims of privilege until an appeal after trial. ${ }^{28}$ Unlike appeals under the Perlman ex-

stitutional claims, see In re Oberkoetter, 612 F.2d 15, 18 (1st Cir. 1980), the argument is unpersuasive because nonconstitutional privileges deserve and receive the same protection as their constitutional counterparts in other contexts. See, e.g., In re Grand Jury Proceedings, 601 F.2d 162, 169 (5th Cir. 1979) (rule protecting witnesses from surrendering constitutional privileges extended to include common law and statutory privileges).

${ }_{27} 28$ U.S.C. \& 1292(b) (1976). In relevant part, this section provides:

When a district judge . . . shall be of the opinion that such order involves a controlling question of law as to which there is substantial ground for difference of opinion and that an immediate appeal from the order may materially advance the ultimate termination of the litigation, he shall so state in writing. . . . The Court of Appeals may thereupon, in its discretion, permit an appeal to be taken from such order.

${ }^{28}$ See, e.g., United States v. Bonnell, 483 F. Supp. 1091 (D. Minn. 1979) (certifying under section 1292(b) questions whether document subpoenaed by grand jury was privileged attorney-client communication or attorney's work product and whether subpoena violated intervenor's fifth amendment rights); In re Grand Jury Investigation, 338 F. Supp. 1379 (W.D. Pa. 1972) (certifying under section 1292(b) question whether documents subpoenaed by grand jury were privileged under the fifth amendment). But see In re Oswalt, 607 F.2d 645 (5th Cir. 1979) (absent certification by district court, denial of motion to quash grand jury subpoene is not appealable under section 1292(b)); In re April 1977 Grand Jury Subpoenas, 584 F.2d 1366 (6th Cir. 1978) (district court's order relating to grand jury criminal proceeding not appealable under section 1292 (b) because such a proceeding not a "civil action" within the Act), cert. denied, 440 U.S. 934 (1979).

Outside of the grand jury context, some courts have permitted parties under section 1292(b) to appeal motions to quash subpoenas seeking allegedly privileged information. See, e.g., Garner v. Wolfinbarger, 430 F.2d 1093 (5th Cir. 1970) (remanding appeal under section 1292(b) involving corporation's claim of attorney-client privilege against plaintiff-stockholders for consideration whether good cause for disclosure of privileged information existed), cert. denied, 401 U.S. 974 (1971). But see SEC v. Canadian Javelin, Ltd., 451 F. Supp. 594 (D.D.C. 1978) (court's order denying corporation's motion to quash subpoena on basis of attorney-client privilege not certified under section 1292 (b) because interlocutory appeal on 
ception, however, appeals under section 1292 (b) are discretionary ${ }^{29}$ and limited to situations where interlocutory review might prevent protracted and expensive litigation. ${ }^{30}$

Other exceptions to the final decision rule also are often inadequate substitutes for the Perlman exception. In the grand jury context, a writ of mandamus ${ }^{31}$ can be issued only where a district judge engages in such "extraordinary" abuse of power that "justice requires immediate review." A2 And the collateral order exception to section 1291, ${ }^{\text {ss }}$ which several courts have used to grant immediate

the privilege question would cause further undue delay).

29 The district court has complete discretion whether to certify the question for appeal. American Bar Ass'n, Report of Special Comm. on Fed. Rules of Procedure, 38 F.R.D. 95, 104 (1965); Gellhorn \& Larsen, Interlocutory Appeal Procedures in Administrative Hearings, 70 MiCk. L. REv. 109, 137 (1971) ("District courts . . . have not been overly sympathetic to claims of error. Neither have they been easily persuaded that the order involves a 'controlling question of law' or that immediate appeal will speed the final determination.") (citations omitted). The courts of appeals can deny review of a certified question for any reason, including congested dockets. Hearings on H.R. 6238 and H.R. 7260 Before Subcomm. No. 3 of the House Comm. on the Judiciary, 85th Cong., 2d Sess. 21 (1958) (statement of Judge Maris).

${ }^{30}$ S. Rep. No. 2434, 85th Cong., 2d Sess. 3, reprinted in 1958 U.S. Code Cong. \& AD. News 5255, 5260. See Note, Interlocutory Appeals in the Federal Courts Under 28 U.S.C. \& 1292(b), 88 HaRv. L. REv. 607, 617-28 (1975).

Section 1292(b) applies only to "civil actions." The Sixth Circuit has held that a grand jury proceeding is not a civil action under section 1292(b), basing its conclusion on the Supreme Court's decisions disapproving appellate interruption of the grand jury's investigations. In re April 1977 Grand Jury Subpoenas, 584 F.2d 1366, 1368-69 (6th Cir. 1978), cert. denied, 440 U.S. 934 (1979). Most courts, however, have labelled a grand jury proceeding a "civil action" under section 1292(b). See, e.g., In re Oswalt, 607 F.2d 645, 648 (5th Cir. 1979); In re Grand Jury Proceedings, 580 F.2d 13, 17 (1st Cir. 1978); In re Doe, 546 F.2d 498, 501-02 (2d Cir. 1976); In re Grand Jury Impaneled Jan. 21, 1975, 541 F.2d 373, 376 (3d Cir. 1976); United States v. Bonnell, 483 F. Supp. 1091, 1093 (D. Minn. 1979).

31 The writ is issued under the All Writs Act, 28 U.S.C. \$ 1651(a) (1976).

* In re Grand Jury Subpoenas, April, 1978, 581 F.2d 1103, 1107 (4th Cir. 1978) (denying petitioner's request for writ of mandamus directing district court to hold an evidentiary hearing on the allegation that the grand jury process had been abused, arguing that petitioner's interests were protected by FED. R. CRIM. P. 6(e), which eliminated the need for extraordinary appellate relief), cert. denied, 440 U.S. 971 (1979). Accord, In re Special March 1974 Grand Jury, 541 F.2d 373 (7th Cir. 1976), cert. denied, 430 U.S. 929 (1977). See also Allied Chem. Corp. v. Daifion, Inc., 449 U.S. 33, 36 (1980) (per curiam) (writ should "hardly ever" be granted to review otherwise interlocutory order); De Beers Consol. Mines, Ltd. v. United States, 325 U.S. 212, 217 (1945) (writ not issued for mere error but only when court has no judicial power to do what it purports to do); Note, Supervisory and Advisory Mandamus Under the All Writs Act, 86 HARv. I. RBv. 595 (1973). But see United States v. United States Dist. Court, 238 F.2d 713 (4th Cir. 1956) (issuing mandamus directing district court to modify order involving subpoenas for production of documents before grand jury), cert. denied, 352 U.S. 981 (1957).

23 This exception, announced in Cohen v. Beneficial Indus. Loan Corp., 337 U.S. 541 (1949), provides for immediate appellate review of court orders that "conclusively determine the disputed question, resolve an important issue completely separate from the merits of the action and . . . [are] effectively unreviewable on appeal from final judgment." Coopers \& 
appeal to subpoenaed witnesses asserting a privilege in information, $^{\text {s4 }}$ has never been invoked to perfect the appeal of a third party intervenor. ${ }^{35}$

\section{Framework for Analysis: The Perlman Exception as a ConTINUUM}

Situations similar to the narrow facts of the Perlman case still arise, as where an attorney moves to quash a grand jury subpoena issued to a court clerk seeking the attorney's retainer agreements on file with the court. ${ }^{36}$ During the 1970's, however, federal courts dramatically expanded the reach of the Perlman exception on the presumption that intervenors' rights usually would not be protected unless immediate review were granted..$^{37}$ Courts have broadened the exception to include employers' appeals of their motions to quash grand jury subpoenas that were issued to their employees, ${ }^{38}$ clients' appeals of motions to quash grand jury subpoenas issued to their attorneys, ${ }^{89}$ and bank depositors' appeals of their motions to quash grand jury subpoenas issued to officials of the bank. ${ }^{40}$

Lybrand v. Livesay, 437 U.S. 463,468 (1978).

st See, e.g., In re Grand Jury Investigation of Ocean Transp., 604 F.2d 672 (D.C. Cir.) (per curiam) (appealing district court's order denying motion to retain documents accidentally disclosed to Justice Department), cert. denied, 444 U.S. 915 (1979); Socialist Worker's Party v. Grubisic, 604 F.2d 1005 (7th Cir. 1979) (per curiam) (appeal by nonparty deponent of court's order denying his motion to quash subpoena); Covey Oil Co. v. Continental Oil Co., 340 F.2d 993 (10th Cir.) (appeal by nonparty witness of court's order denying motion to quash subpoena), cert. denied, 380 U.S. 964 (1965). But see Kaufman v. Edelstein, 539 F.2d 811 (2d Cir. 1976) (nonparty witness may not use collateral order doctrine to appeal denial of motion to quash subpoena); United States v. Anderson, 464 F.2d 1390 (D.C. Cir. 1972) (same).

ss See In re Sealed Case, 655 F.2d 1298, 1302 n.7 (D.C. Cir. 1981) (implicitly rejecting application of the collateral order doctrine to third-party intervenors).

28 In re Grand Jury Impaneled Jan. 21, 1975, 541 F.2d 373, 376-77 (3d Cir. 1976).

s7 See, e.g., In re Grand Jury Proceedings, 641 F.2d 199 (5th Cir. 1981); In re Berkley \& Co., 629 F.2d 548 (8th Cir. 1980); In re Grand Jury Proceedings, 623 F.2d 122 (2d Cir. 1980); In re November 1979 Grand Jury, 616 F.2d 1021 (7th Cir. 1980); In re Grand Jury Proceedings, 604 F.2d 798 (3d Cir. 1979).

"In re Grand Jury, 619 F.2d 1022, 1024-25 (3d Cir. 1980); see infra notes 55-59 and accompanying text.

30 In re Grand Jury Proceedings, 655 F.2d 882, 885 (8th Cir. 1981); In re Grand Jury Proceedings, 641 F.2d 199, 203 (5th Cir. 1981); Velsicol Chem. Corp. v. Parsons, 561 F.2d 671, 674 (7th Cir. 1977), cert. denied, 435 U.S. 942 (1978).

10 Harris v. United States, 413 F.2d 316, 316 (9th Cir. 1969); see also American Meat Processors Ass'n v. United States, 561 F.2d 109, 110 n.2 (8th Cir. 1977) (appeal by trade association members of denial of their motion to quash grand jury subpoena issued to fellow association member seeking records allegedly privileged by first amendment associational rights). 
Thus the Perlman exception, designed to apply to a "limited class of cases," far different from the "unusual"42 circumstances in Perlman. Courts of appeals expanding the exception have enunciated no limiting principles to prevent it from swallowing up the rule that contempt is required to perfect immediate appeals. ${ }^{43}$ They have failed to follow the Supreme Court's direction that in deciding questions of finality, "the danger of denying justice by delay" must be balanced against the "important competing considerations" of "the inconvenience and costs of piecemeal appeals." "44 The policy against piecemeal appeals has heightened significance in the grand jury context, for grand juries cannot function properly if they are constantly interrupted by appeals. ${ }^{45}$ Where federal court dockets

In a unique line of cases, the Fifth Circuit has created a governmental privilege variation to the Perlman exception that arguably swallows up the contempt-to-perfect rule. In Cates v. LTV Aerospace Corp., 480 F.2d 620, 622 (5th Cir. 1973), the court extended the exception to allow the Department of the Navy, asserting an executive privilege in the subpoenaed information, to appeal the order to produce the information even though the order was directed at the Department of the Navy itself. In effect, the court allowed the government to appeal without suffering contempt, thus totally circumventing the contempt route of appeal. See also Carr v. Monroe Mfg. Co., 431 F.2d 384, 387 (5th Cir. 1970), cert. denied, 400 U.S. 1000 (1971); Overby v. United States Fidelity \& Guar. Co., 224 F.2d 158, 162 (5th Cir. 1955). The Fifth Circuit recently, though reluctantly, reaffirmed this variation. See Branch v. Phillips Petroleum Co., 638 F.2d 873, 877-78 (5th Cir. 1981) (following Cates although asserting that there is no reason to allow a governmental body to appeal a subpoena without contempt while requiring a private party to perfect the appeal by contempt). For criticism of the Fifth Circuit's doctrine, see In re Grand Jury Subpoena, 607 F.2d 566, 571 (2d Cir. 1979) (Fifth Circuit's extension of Perlman implicitly rejects the contempt route to appealability required by the Supreme Court).

12 United States v. Ryan, 402 U.S. 530, 533 (1971), quoted with approval in United States v. Nixon, 418 U.S. 683,691 (1974).

${ }^{42}$ National Super Spuds, Inc. v. New York Mercantile Exch., 591 F.2d 174, 178 (2d Cir. 1979). One explanation for this expansion of the Perlman exception is Congress's enactment of the "recalcitrant witness" statute, 28 U.S.C. § 1826 (1976), which empowers federal judges summarily to confine grand jury witnesses who refuse "without just cause" to comply with a court's order. Once courts were given this power, witnesses and interested parties would understandably try to avoid this punishment. Conceivably, the Perlman exception was expanded to circumvent this penalty, allowing both the subpoenaed party and the intervenor to avoid confinement and to obtain review of the claim. One factor that cuts against this explanation is that section 1826 was designed to codify the existing civil contempt practice with respect to recalcitrant witnesses in federal grand jury and court proceedings. See H.R. REP. No. 1549, 91st Cong., 2d Sess. 33, reprinted in 1970 U.S. Code Cong. \& AD. News 4007,4008 . If section 1826 merely codified the prevailing practice, it remains a mystery why reliance on the Perlman exception mushroomed in the 1970's.

4s See supra notes 3-4 and accompanying text.

“ Gillespie v. United States Steel Corp., 379 U.S. 148, 152-53 (1964) (quoting Dickinson v. Petroleum Conversion Corp., 338 U.S. 507, 511 (1950)).

45 See Cobbledick v. United States, 309 U.S. 323, 327-28 (1940) (appellate disruption of grand jury process strongly disfavored because piecemeal disposition would lead to a "leaden-footed" system and would hinder efficient administration of the criminal justice 
already are overburdened with motions at every stage of litigation, ${ }^{48}$ courts must respect the finality requirement if the system is to function.

Consideration of these factors demonstrates that an intervenor's interlocutory appeal should be allowed only where the relationship between the subpoenaed party and the intervenor is so attenuated that the contempt route is realistically unfeasible. ${ }^{47}$ To determine whether a particular relationship warrants this application of the Perlman exception, this comment proposes as a framework for analysis the use of a continuum based on the nature of the relationship between the subpoenaed party and the intervenor. At one end of this continuum is Perlman, where the subpoenaed witness has no connection with the intervenor. ${ }^{48}$ At the other end, in relationships such as master and servant, the intervenor effectively controls the witness. "Effective control" is not a literal concept; rather, it describes a nexus justifying a presumption that the interests of the intervenor are sufficiently related to those of the witness to eliminate the need for the intervenor to invoke the Perlman exception. In many situations of effective control, the intervenor can be expected to exercise sufficient influence over the witness that he will persuade the witness to suffer contempt to perfect an immediate appeal. ${ }^{90}$ In other situations, the intervenor colludes with the witness: the witness, who has been given information by the intervenor, refuses to contest the order, thereby laying the groundwork for the intervenor's argument that invocation of the Perlman exception is necessary.

system).

10 In 1981, court of appeals filings numbered 26,362 , an increase of almost $14 \%$ over the previous year; district court filings expanded to 211,863 , a $7 \%$ increase over the previous year. "[T] $]$ he problem these case filings present is not simply workload on the courts or delay for the litigants, but a real threat to the quality of federal justice." W. Burger, Year-End Report on the Judiciary 2 (December 28, 1981) (on file with The University of Chicago Law Review).

47 In addition to showing that the contempt process cannot be relied upon, the intervenor must also demonstrate that delay in appealing the subpoena would result in injustice. See Gillespie v. United States Steel Corp., 379 U.S. 148, 152-53 (1964). The alternatives, though, will usually be unattractive. Courts have not invoked section 1292(b) to certify intervenors' claims of privilege, and in any event that route is discretionary. See supra notes 27-30 and accompanying text. Moreover, although an intervenor can also protect his claim by raising it at trial in a suppression hearing, see infra notes 79-82 and accompanying text, this protection may frequently be too late; "courts cannot always 'unring the bell' once information has been released." Maness v. Meyers, 419 U.S. 449, 460 (1975). See also infra note 57.

${ }^{48}$ See supra notes 15-20 and accompanying text.

40 See infra notes $56-57,59,62-72$, and accompanying text.

so See infra notes $58,73-78$, and accompanying text. 
Determining effective control is easy at either end of this continuum. At the Perlman pole, the lack of any relationship between the parties eliminates the possibility that the intervenor will influence the witness. Such a disinterested witness presumably will not collude with the intervenor or risk contempt to perfect an appeal to protect the intervenor's claim, and the Perlman exception therefore should apply. At the master-servant pole, the relationship is defined by the intervenor's ability to control the witness. There is no need to apply the exception in this case because the witness presumably will protect the intervenor's claim by suffering contempt.

Relationships falling between the ends of the continuum are more difficult to categorize. As the nature of the relationship moves away from the Perlman pole, the need for adhering to the final decision rule becomes more pronounced because the probability increases that the intervenor effectively controls the subpoenaed party, thus increasing the opportunity for collusive appeals.

Courts can rely on several factors to determine whether intervenors effectively control witnesses in relationships that lie between the continuum's poles. The relationship's origin, continuity, and duration should be considered. The relationship's origin-whether it is based on contract, agency, trust, or other grounds-points toward another factor: the availability of sanctions that the intervenor might use to coerce the witness. A third helpful inquiry concerns the existence of any ethical, legal, or fiduciary duties that might affect the witness's decision to risk contempt. Finally, courts should consider the effect that the witness's self-interest, such as maintaining a respectable business reputation, might have on a decision to protect the intervenor by risking contempt. Although these factors are not exhaustive, they highlight promising areas of inquiry for courts to use in deciding whether a particular relationship warrants application of the Perlman exception.

\section{Applying the ContinuUm}

Using the continuum outlined above, this part analyzes case patterns to illustrate how courts can effectively limit the scope of the Perlman exception. Cases at the opposite ends of the continuum will be examined first, and then the more difficult cases in between will be analyzed. 
A. The Perlman Situation

Where there is no recognizable relationship between the subpoenaed party and the intervenor, and the intervenor asserts a claim of privilege in the subpoenaed information, courts properly have applied the Perlman exception. The intervenor cannot effectively control the witness, and the lack of any relationship between the parties eliminates the possibility that the intervenor might influence the witness's behavior. Accordingly, courts have applied the exception where a court clerk, ${ }^{81}$ a government agency, ${ }^{82}$ or some other unrelated and disinterested party ${ }^{53}$ is subpoenaed to disclose the intervenor's privileged information. In each of these situations, the intervenor could not possibly persuade the witness to risk contempt to perfect an appeal. Reminiscent of the circumstances of Perlman itself, ${ }^{54}$ these cases present the most compelling scenarios for applying the exception.

\section{B. Employer-Employee Relationships}

Courts typically have applied the Perlman exception to employer-employee cases by assuming, without examining the particular circumstances, that the employee could not be expected to risk contempt to protect his employer's interests..$^{5 \mathrm{~b}}$ Closer scrutiny, however, reveals that this relationship lies closer to the master-servant end of the continuum, where the exception should never be applied, than to the Perlman end. Thus a court should carefully examine each relationship to determine if the employer effectively controls the employee's decision to risk contempt or is in a position to collude with the employee.

Several factors should be considered. Relations of trust and

s1 See, e.g., In re Grand Jury Impaneled Jan. 21, 1975, 541 F.2d 373, 377 (3d Cir. 1976) (lawyer permitted to appeal an order compelling a court clerk to produce before a grand jury the lawyer's retainer agreements, which had been deposited with the clerk pursuant to a local court rule).

${ }^{62}$ See, e.g., In re Berkley \& Co., 629 F.2d 548, 551-52 (8th Cir. 1980) (corporation permitted to appeal denial of motion to prevent disclosure of allegedly privileged documents in the government's custody).

s2 See, e.g., In re Grand Jury Investigation, 587 F.2d 589, 592 n.3 (3d Cir. 1978) (United States congressman permitted to appeal the denial of his motion to quash a grand jury subpoena issued to the Clerk of the House of Representatives to produce the congressman's telephone records). Oddly enough, the Third Circuit never mentioned the Perlman exception in this decision; it simply assumed that the order was appealable.

- See supra notes 15-20 and accompanying text.

ss See, e.g., In re Grand Jury, 619 F.2d 1022, 1024-25 (3d Cir. 1980) (corporation permitted to appeal court's order denying its motion to quash grand jury subpoenas issued to its employees). 
confidence between the employer and employee inhere in many jobs. In United States $v$. Doe, ${ }^{\mathrm{s}}$ for example, the First Circuit allowed a United States Senator to appeal the denial of his motion to quash a grand jury subpoena issued to his legislative aide. Such a relationship is based on mutual trust and confidence, however, and it seems plausible that one of the aide's duties would be to preserve the Senator's privileged communications, even where faced with contempt. In addition, the aide has an incentive to obey the Senator's orders if he wants to be known as a competent and trustworthy legislative assistant. These factors demonstrate the inappropriateness of applying the Perlman exception where the employee can be expected to risk contempt for the employer's benefit. ${ }^{\text {s? }}$

In addition, one could imagine a case in which an employer might order the employee to refuse to suffer contempt, thereby creating a situation in which the employer-intervenor could invoke the Perlman exception. In such a case, the employer seeks to orchestrate events to his advantage by pretending that the subpoenaed employee acts independently of his concerns. The Perlman exception should not be applicable in such sham proceedings to avoid the final decision rule by artificially creating an appealable

se 455 F.2d 753 (1st Cir.), vacated and remanded on other grounds sub nom. Gravel v. United States, 408 U.S. 606 (1972). Senator Gravel of Alaska was Chairman of the Senate Subcommittee on Public Buildings and Grounds. After mysteriously acquiring the "Pentagon Papers," he read excerpts before his subcommittee and introduced the documents as an exhibit. A federal grand jury was convened to investigate Gravel's acquisition of these documents, and subpoenaed his legislative aide and a publisher. The Senator intervened and argued that his privilege under the speech and debate clause, U.S. ConsT. art. I, $\& 6$, required that the subpoena be quashed. $455 \mathrm{~F} .2 \mathrm{~d}$ at 756.

87 The Government attempted in Doe to take the case outside of the Perlman exception by arguing that Senator Gravel would not suffer irreparable harm if the grand jury heard the testimony and that no injury to him was cognizable unless and until he was indicted. The court disagreed, interpreting Perlman as requiring a court to assume the Senator's claim of irreparable injury to be correct. 455 F.2d at 757. The Doe court has been the only court to address this point.

This response avoids the critical inquiry involved in the Perlman exception cases. The issue is not whether to presume irreparable injury, but rather whether the subpoenaed party may be presumed capable under the circumstances of preserving the intervenor's appeal. Given the Doe court's presumption of irreparable injury, every court would be bound to apply Perlman as long as the intervenor presented a prima facie showing of such injury. To preserve the narrow scope of the Perlman exception, courts should focus on the relationship between the parties rather than on the type of injury alleged. But see In re Grand Jury Proceedings, 604 F.2d 804 (3d Cir. 1979), where the court refused to apply the Perlman exception to allow a corporation to appeal an order denying its motion to terminate grand jury proceedings and to quash subpoenas issued to its employees. The court reasoned that the exception was not applicable because the government, not the subpoenaed employees, possessed the documents sought by the grand jury. Id. at 805 . 
order, when the contempt route would be available..$^{58}$

Moreover, most employer-employee relationships involve some degree of employer influence and control..$^{\text {se }}$ The typical employer, like a master, influences the employee with threats of sanctions, and the employee, wary of the possibility of being fired, is reluctant to disregard the employer's orders. The employer also can be expected to offer incentives to ensure employee support. For example, although an employee might be reluctant to carry the financial burden of suffering contempt for his employer's sake, an employer who wants to guard information presumably will underwrite his employee's litigation expenses and possible contempt citation. It is in the employer's own self-interest to encourage his employees to act as his shields. An employer who refuses to support his employees should not be permitted thereby to bootstrap his way into intervention and third-party interlocutory appeal under the Perlman exception.

se Judge Friendly, in National Super Spuds, Inc. v. New York Mercantile Exch., 591 F.2d 174, 179 n.7 (2d Cir. 1979), recognized that the Perlman exception should not apply where the employer orders the employee not to testify and the employee dutifully complies. Where the employee complies with such an order, it is plausible that the employee would also comply with other orders issued by the employer. Thus the employee might risk contempt to protect the employer, or might obey the employer's order not to suffer contempt in order to perfect a sham Perlman appeal.

s The District of Columbia and Second Circuits have focused on this control element in refusing to extend the Perlman exception to employer-employee relationships. In In re Sealed Case, 655 F.2d 1298, 1301 (D.C. Cir. 1981), Judge Ginsburg concluded that because an employer exercises significant control over an employee, the Perlman exception "flags when an employer moves to quash a subpoena addressed to such an employee."

Judge Friendly, speaking for the Second Circuit, has argued that there is no parallel between the circumstances in Perlman and the employer-employee situation: it was "unimaginable" that the court clerk would risk contempt to assist Perlman, but employees are susceptible to employer control and often participate in the relationship out of which the alleged privilege emerges. See National Super Spuds, Inc. v. New York Mercantile Exch., 591 F.2d 174, 179 \& n.7 (2d Cir. 1979) (refusing to extend the Perlman exception to allow the Commodity Futures Trading Commission to appeal an order compelling employee's testimony before a grand jury; counsel for CFTC had advised the employee not to testify, claiming that the testimony was protected by governmental privilege). See also In re Grand Jury Investigation, 318 F.2d 533 (2d Cir. 1962) (Friendly, J.) (refusing to allow corporation to appeal court's denial of its motion to limit subpoenas issued to corporate officials), cert. denied, 375 U.S. 802 (1963).

In National Super Spuds, Judge Friendly suggested that where a court finds that the employer has directed its employee-witness to flout a court's order, sanctions should be imposed directly on the employer rather than on the obedient employee. He argued that such direct sanctions "might have the salutary effect of curtailing attempts to appeal from decisions denying insubstantial or unimportant claims of . . p privilege." 591 F.2d at 108 n.9. 


\section{Attorney-Client Relationships}

Courts disagree over the applicability of the Perlman exception when an attorney is subpoenaed to testify before a grand jury, and his client, asserting an attorney-client privilege, seeks to appeal the denial of a motion to quash the subpoena. Although most circuits addressing the issue have expanded the Perlman exception to cover this situation, ${ }^{60}$ a well-reasoned minority argues convincingly to the contrary. ${ }^{81}$

Courts applying the exception to the attorney-client relationship presume that an attorney cannot be expected to suffer contempt for his client's sake. ${ }^{.2}$ The Fifth Circuit, for example, has asserted that an attorney's willingness to protect his client's privilege in the face of a contempt citation varies greatly and depends on the value of the client's business and the particular relationship. The court has expressed "reluctan[ce] to pin the appealability of a district court order upon such precarious considerations." ${ }^{\text {Bs }}$

The particular nature of the attorney-client relationship renders this assumption suspect. Like journalists, ${ }^{64}$ many attorneys have accepted contempt citations to protect their clients' confidences. ${ }^{65}$ As Judge Wyzanski has noted, an attorney, "in his client's interest and as proof of his own stout-heartedness," will often be willing to defy a court's order and risk a contempt citation to render the client's claim appealable. ${ }^{68}$ Moreover, the attorney who wishes to maintain a professional reputation for providing compe-

${ }^{60}$ See In re Grand Jury Proceedings, 655 F.2d 882 (8th Cir. 1981); In re Grand Jury Proceedings, 641 F.2d 199 (5th Cir. 1981); In re Grand Jury Proceedings, 623 F.2d 122 (2d Cir. 1980); In re November 1979 Grand Jury, 616 F.2d 1021 (7th Cir. 1980); In re Grand Jury Proceedings, 604 F.2d 798 (3d Cir. 1979).

1 See In re Sealed Case, 655 F.2d 1298 (D.C. Cir. 1981); In re Oberkoetter, 612 F.2d 15 (1st Cir. 1980).

${ }^{62}$ See, e.g., In re Grand Jury Proceedings, 655 F.2d 882, 885 (8th Cir. 1981); In re Grand Jury Proceedings, 641 F.2d 199, 203 (5th Cir. 1981); In re Grand Jury Proceedings, 623 F.2d 122, 124 (2d Cir. 1980); In re November 1979 Grand Jury, 616 F.2d 1021, 1025 (7th Cir. 1980); In re Grand Jury Proceedings, 604 F.2d 798, 801 (3d Cir. 1979).

as In re Grand Jury Proceedings, 641 F.2d 199, 202 (5th Cir. 1981).

64 See, e.g., In re Myron Farber, 78 N.J. 259, 394 A.2d 330 (newspaper reporter fined and imprisoned for civil contempt for refusing to disclose confidential sources of information subpoenaed for use in murder trial), cert. denied, 439 U.S. 997 (1978).

os See, e.g., In re Grand Jury Proceedings, 517 F.2d 666 (5th Cir. 1975) (holding five attorneys in contempt for refusing to comply with grand jury subpoenas seeking information about clients); In re Grand Jury Appearance of Michaelson, 511 F.2d 882 (9th Cir.) (holding attorney in contempt for refusing to comply with grand jury subpoena questioning his fee arrangement with a client), cert. denied, 421 U.S. 978 (1975).

so In re Oberkoetter, 612 F.2d 15, 18 (1st Cir. 1980) (holding Perlman exception inapplicable to attorney-client relationships). 
tent legal services can be expected to guard his clients' interests; prospective clients will not flock to an attorney who is known to surrender confidential information without a fight. ${ }^{67}$

In addition to his own integrity and economic interest, an attorney might have a fiduciary duty to his client to risk contempt if he believes the client's claim is worthy. ${ }^{68}$ For example, in In re Grand Jury Proceedings, ${ }^{69}$ the Second Circuit permitted the client to appeal because the attorney could not be expected to risk contempt, ${ }^{70}$ even though the local bar association had concluded that, under New York's ethics rules, the attorney owed a duty to his client to disobey the subpoena. ${ }^{71}$ The bar association assumed that an ethical attorney would suffer the contempt citation, and there was no reason for the court to presume that the attorney would act unethically. Because of the bar association's ruling, failure to suffer contempt would make the attorney liable in a malpractice action for breach of duty. ${ }^{72}$ The court's application of the Perlman exception fails its own test because there was no reason for the court to doubt that the attorney would follow his client's wishes, especially if he knew that the Perlman exception were not available to per-

4 See In re Sealed Case, 655 F.2d 1298, 1301 (D.C. Cir. 1981) (because lawyer shared the client's interests in withholding the information and had a "special stake in resisting production," Perlman exception should not be applied).

cs It is unclear whether an attorney would be liable in a malpractice action for complying with a subpoena against his client's wishes under the threat of contempt. The attorney's compliance with the court's order seems consistent with the Code of Professional Responsibility; Disciplinary Rule 4-101(C)(2) provides that a lawyer may reveal "[c]onfidences or secrets when permitted under Disciplinary Rules or required by law or court order." One plausible reading of the rule would authorize disclosure only if the court order were valid. Accordingly, the client might have a cause of action against the attorney if the attorney complied with the subpoena despite knowledge that the subpoena impermissibly violated the attorney-client privilege.

The uncertainty surrounding this issue results largely from the fact that clients rarely sue their attorneys for unauthorized disclosure of privileged information. The few cases in which clients have sued involve intentional attorney disclosures. See, e.g., Lakoff v. Lionel Corp., 207 Misc. 319, 137 N.Y.S.2d 806 (Sup. Ct. 1955); Taylor v. Blacklow, 3 Bing. N.C. 235, 132 Eng. Rep. 401 (C.P. 1836). For an explanation of clients' infrequent recourse to malpractice actions, see Note, The Attorney-Client Privilege After Attorney Disclosure, 78 Mich. L. Rev. 927, 937-38 (1980).

- 623 F.2d 122 (2d Cir. 1980). The grand jury was investigating illegal arms sales, and the attorney was subpoenaed to provide documents relating to his client's activities. Id. at 127. The client-intervenor claimed that production of the subpoenaed material would violate his fifth amendment privilege against self-incrimination. Id. at 125.

70 Id. at 125. The author of this opinion, Judge Mulligan, had sat with Judge Friendly on the panel that decided National Super Spuds. See supra notes 58-59 and accompanying text. Judge Mulligan's wholesale endorsement of the Perlman exception in this case is a mystery, considering his acquiescence in Judge Friendly's earlier criticism of the doctrine.

${ }^{71} 623$ F.2d at 124.

72 See supra note 68. 
fect an appeal. This case shows the propensity of the exception to create unnecessary appeals.

The close relationship between an attorney and his client also points to the likelihood of collusion between them if courts continue to allow appeals under Perlman. Where a client-intervenor need only inform the court that his attorney will not risk contempt, the "harsh choice" sought to be imposed by section 1291 is circumvented..$^{73}$ In In re Sealed Case, ${ }^{74}$ for example, the District of Columbia Circuit recognized the danger of allowing an attorney and his client to orchestrate an appeal through the Perlman exception. ${ }^{75}$ Judge Ginsburg's opinion argued that the client, by deliberately entrusting privileged documents to his attorney, assumed that the attorney would resist production and suffer contempt if the client wished to secure appellate review. ${ }^{78}$ Accordingly, she expressed little sympathy for the client's assertion that it should be permitted to intervene and secure an interlocutory appeal from the court's order to produce. ${ }^{77}$

The majority-view courts also have expressed concern with the prospect of a client suffering irreparable harm if he could not immediately appeal, arguing that an attorney's disclosure of allegedly privileged information would prejudice the client either by leading to an indictment or by destroying the privilege. ${ }^{78}$ The irreparable

73 See supra notes 11-14 and accompanying text.

74655 F.2d 1298 (D.C. Cir. 1981).

78 Id. at 1301. See supra note 58 and accompanying text.

78 655 F.2d at 1302.

77 Id. Judge Ginsburg, opting for a restrictive reading of the Perlman exception, rejected the corporation's contention that Perlman established a general third-party exception to section 1291. Id. She stressed that the Supreme Court has never interpreted Perlman so broadly, and that Perlman could not be extended to the attorney-client situation "without enlarging the exception to the point at which it engulfs the rule." Id.

Judge Wyzanski has also looked unfavorably on a broad reading of the Perlman exception. Reviewing the exception in In re Oberkoetter, 612 F.2d 15, 18 (1st Cir. 1980), he showed a subtle annoyance with the Supreme Court's tolerance of the expansion. He speculated, however, that if the Court now addressed the question whether a third party has a direct appeal from an order compelling someone to disclose an allegedly privileged matter before the grand jury, the Court would answer "no" and would either overrule or distinguish Perlman. Id.

Acknowledging these attacks, Judge Arnold, speaking for the court in In re Grand Jury Proceedings, 655 F.2d 882 (8th Cir. 1981), elected to abide by the exception because "whatever the merits of Perlman as an academic matter, it remains an opinion of the Supreme Court ...., never overruled, and recently cited with approval," id. at 884 (citation omitted).

78 See, e.g., In re Grand Jury Proceedings, 641 F.2d 199, 202 (5th Cir. 1981); In re November 1979 Grand Jury, 616 F.2d 1021, 1025 (7th Cir. 1980); Velsicol Chem. Corp. v. Parsons, 561 F.2d 671, 674 (7th Cir. 1977), cert. denied, 435 U.S. 942 (1978).

Courts might also be concerned with the "chilling effect" of such disclosures on the 
harm exception, however, is also unpersuasive. As Judge Ginsburg has noted, denying an appeal under Perlman "will not 'render impossible' appellate review of [the client's] claims."79 If the attorney's disclosure leads to an indictment, the client can object at trial to the introduction of evidence based on the attorney's grand jury testimony if the attorney-client privilege is found to be valid. ${ }^{\mathrm{Bo}}$ In addition, it is not certain that an attorney's forced disclosure before a grand jury dissipates the privilege. Waiver, like the privilege itself, belongs solely to the client and not to the attorney. ${ }^{81}$ Presumably the client cannot be held to have waived the privilege where the attorney complied with the court's order without the client's consent. ${ }^{82}$

The disagreement among the circuits over the Perlman exception's applicability to the attorney-client relationship highlights the consequences of extending the exception indiscriminately without scrutinizing the relationship to find whether the intervenor can control the witness's decision to risk contempt. Courts have approached the issue from two distinct premises. Those courts that have extended the exception to include the attorney-client relationship assume the exception's validity and merely determine

attorney-client privilege if clients are not permitted immediate appeals, on the ground that clients will be less likely to confide in their lawyers knowing that they cannot prevent disclosures to the grand jury. See In re Berkley \& Co., 629 F.2d 548, 552 (8th Cir. 1980). This concern, however, erroneously assumes that the client is powerless to challenge such disclosures in later proceedings. See infra notes 79-82 and accompanying text.

70 In re Sealed Case, 655 F.2d 1298, 1301 (D.C. Cir. 1981).

so See United States v. Blue, 384 U.S. 251, 255 (1966).

si See, e.g., Esposito v. United States, 436 F.2d 603, 606 (9th Cir. 1970); Republic Gear Co. v. Borg-Warner Corp., 381 F.2d 551, 556 (2d Cir. 1967); 8 J. Wigmore, Evidence § 2327 (J. McNaughton rev. ed. 1961 \& Supp. 1981).

s2 See Nixon v. Sampson, 389 F. Supp. 107, 153 (D.D.C. 1975) ("When an attorney is subpoenaed or summoned to testify about confidential communications protected by the attorney-client privilege, he may not do so without the informed consent of his client."); People v. Kor, 129 Cal. App. 2d 436, 277 P.2d 94, 98 (1954) (client held not to have waived attorney-client privilege where attorney was compelled to testify under threat of contempt citation); Note, supra note 68 , at $929-39$ (discussion of various techniques used by courts to determine whether attorneys' disclosures constitute waivers). See also FrD. R. Evid. 512 (not enacted), which provides that "[e]vidence of a statement or other disclosure of privileged matter is not admissible against the holder of the privilege if the disclosure was (a) compelled erroneously or (b) made without opportunity to claim the privilege."

See also In re Oberkoetter, 612 F.2d 15, 17 (1st Cir. 1980), where the court rejected extension of the Perlman exception to the attorney-client situation because the issues likely to be raised were easily within the competence of a district judge: his ruling was "so likely to be fully satisfactory that in the usual case there is no public policy favoring any form of review." Even the Fifth Circuit, an ardent supporter of a broad application of Perlman, has noted that issues concerning the attorney-client privilege are "rarely complex and may be disposed of without oral argument in nearly all cases." In re Grand Jury Proceedings, 641 F.2d 199, 203 (5th Cir. 1981). 
whether the subpoenaed party reasonably can be expected to risk contempt to protect the intervenor's claim. Finding such behavior unlikely, they conclude that the Perlman exception must be applied to preserve appellate review of a deserving claim. Courts that have rejected extension of the exception, on the other hand, assume that appellate review of an interlocutory order is a privilege that conflicts with the policies behind section 1291 . They are reluctant to grant appeal on the asserted ground that the subpoenaed party cannot be expected to risk contempt, especially when they confront the typical attorney-client relationship, where the client exercises influence and control over the attorney's actions.

One difficulty with many of these latter cases is that they contest the majority's reasoning on specific factual grounds, thus disguising the underlying issue: whether the judicial system can operate properly if all interlocutory orders affecting intervenors' rights are made immediately appealable. There will be cases where the facts show that an attorney will not risk contempt for his client. These cases, however, which may well be the exception rather than the rule, should not automatically legitimize the extension of Perlman.

\section{Troublesome Cases}

Other cases involving a recognizable relationship between the subpoenaed party and the intervenor present the most troublesome issues in determining the application of the Perlman exception. These cases are difficult to resolve because the nexus between the parties places their relationship somewhere in the middle of the continuum, where it is uncertain whether the intervenor can be presumed to control the witness effectively. In these cases, courts must scrutinize the relationship, looking for such factors as the availability of private sanctions, the nature of the transaction, and the presence of self-interest, to determine whether the case properly belongs closer to the Perlman pole or to the master-servant pole of the continuum. ${ }^{83}$

Although there are no easy answers, the continuum analysis leads to more principled and rational decisions about whether an intervenor effectively controls a witness, so that the contempt route to review is adequate. For example, courts should examine the voluntariness of the transaction that initially created the relationship. If the intervenor deliberately chose to provide another

ss See supra notes 47-50 and accompanying text. 
party with information that might later be subject to subpoena, he should be presumed to be barred from invoking the Perlman exception. Although this test is harsh, it would provide courts with a precise guideline that would minimize the scope of appellate factfinding and would guard against collusive actions to circumvent the final decision rule through manipulation of the Perlman exception. To shift the presumption, the intervenor might emphasize the particular nature of the transaction, the lack of a continuing relationship, or the accidental or innocent circumstances surrounding the transaction.

Many courts in such situations have uniformly applied the Perlman exception, assuming that the subpoenaed party would never risk contempt to perfect the intervenor's appeal. ${ }^{84}$ In American Meat Processors Association v. United States, ${ }^{85}$ for example, the Eighth Circuit permitted several members of a trade association to appeal from an order denying their motion to quash a subpoena issued to another member. The subpoena sought documents concerning each member's business activities. ${ }^{86}$ It is difficult to understand how the court so easily concluded that the subpoenaed party was sufficiently independent of the intervenors to warrant application of the Perlman exception. Both the subpoenaed party and the intervenors were members of the same association, and all of them were being investigated for organized crime and racketeering activities. Each business had a distinct interest in not disclosing the subpoenaed information, because once that information was released, all members would be potentially indictable. These factors, when considered with the continuing nature of the relationship and the voluntariness of the transfer of information, indicate that the subpoenaed party could be expected to suffer contempt to protect the intervenors' claim. ${ }^{87}$

\footnotetext{
s See, e.g., In re Grand Jury Empanelled Oct. 18, 1979, 633 F.2d 282 (3d Cir. 1980) (intervening lawyer permitted under Perlman exception to appeal an order denying his motion to quash subpoena issued to private investigator whom he had once retained to assist him in defending a client); Harris v. United States, 413 F.2d 316 (9th Cir. 1969) (intervenor, as named party of a trustee account, permitted under Perlman to appeal order denying his motion to quash subpoena issued to official of the bank holding the account).

as 561 F.2d 109 (8th Cir. 1977).

" Id. at 110 n.2. The intervenors claimed that the subpoena, which ordered the trade association to disclose its membership, violated their first amendment rights. Id. at 111 .

"7 In fairness to the court, the subpoenaed party possibly had nothing to fear from the investigation and might have been willing to cooperate with the government to incriminate its fellow members, and thus the court might have been correct in concluding that the subpoenaed party could not be expected to protect the appellants' rights. Yet the subpoenaed party's recalcitrance should not, by itself, confer appealability through Perlman. The subpoenaed party's unwillingness is only a sign of what underlies its relationship with the inter-
} 


\section{Conclusion}

The Perlman exception is just what its name implies: an exception, and not the rule. Congress set forth in section 1291 a policy of restricting appeals to final decisions, and the Supreme Court has recognized that Perlman represents one of a "limited class of cases"8s justifying departure from the rule of absolute finality. Yet many courts of appeals have engaged in unwarranted extension of the exception through a simplistic assumption that subpoenaed witnesses are almost never willing to risk contempt to protect third parties' privileges, thus making most cases immediately appealable. The advantage of this expansion is its ease of application. Its flaw is that it violates the underlying policy against interlocutory appeals.

Appeal through the Perlman route should be allowed only where the subpoenaed party is disinterested and independent of the intervenor and does not share the intervenor's privilege. Only in such a case can it confidently be presumed that the witness will not suffer contempt to perfect an appeal.

This comment has set forth an analytical continuum to assist in assessing the nexuses between witnesses and intervenors. The analysis, based on such factors as the origins and nature of the relationship, the availability to the intervenor of sanctions against the witness, special duties owed by the witness to the intervenor, and common-sense assessments of the parties' self-interests, should assist the courts in pinpointing relationships that are likely to rest on commonality of interest, coercion, or collusion. In such situations the courts should, at the least, invoke a strong presumption against permitting interlocutory appeal by the intervenor. Grounded on realistic distinctions between different types of relationships, the analysis offers a workable judicial approach to the problem. The alternative-wholesale appealability-is unattractive in comparison.

Michael R. Lazerwitz

venors. The relationship, especially the possibility that the intervenors could influence the witness's decision, should determine Perlman's applicability. Because the court failed to examine those factors, it failed to apply the Perlman exception correctly.

ss United States v. Ryan, 402 U.S. 530, 533 (1971). 